Supporting Information

\title{
Phase Transfer of Hydrophobic Nanoparticles Functionalized with Zwitterionic Bisphosphonate Ligands for Renal-Clearable Imaging Nanoprobes
}

\author{
Hao Li, ${ }^{a, b, *}$ Qianfeng Wang,, , $*$ and Guohai Liang ${ }^{a, b, *}$
}

${ }^{a}$ MOE Key Laboratory of Laser Life Science \& Institute of Laser Life Science, College of Biophotonics, South China Normal University, Guangzhou 510631, China.

${ }^{\mathrm{b}}$ Guangdong Provincial Key Laboratory of Laser Life Science, College of Biophotonics, South China Normal University, Guangzhou 510631, China.

${ }^{\mathrm{c}}$ Institute of Science and Technology for Brain-Inspired Intelligence, Fudan University, Shanghai, China.

E-mail: Liangguoh@scnu.edu.cn.

\section{Table of Contents:}

1. Figure $\mathrm{S} 1 .{ }^{1} \mathrm{H}$ NMR spectrum of 3-dimethylaminopropionic acid $\left(\mathrm{D}_{2} \mathrm{O}, 600 \mathrm{MHz}\right)$.

2. Figure S2. ${ }^{1} \mathrm{H}$ NMR spectrum of [3-(dimethylamino)-1-hydroxypropylidene]diphosphonic acid (olpadronic acid) $\left(\mathrm{D}_{2} \mathrm{O}, 400 \mathrm{MHz}\right)$.

3. Figure S3. ${ }^{1} \mathrm{H}$ NMR spectrum of $\mathrm{ZAS}\left(\mathrm{D}_{2} \mathrm{O}, 600 \mathrm{MHz}\right)$.

4. $\quad$ Figure $\mathrm{S} 4 .{ }^{13} \mathrm{C}$ NMR spectrum of ZAS $\left(\mathrm{D}_{2} \mathrm{O}, 600 \mathrm{MHz}\right.$.

5. Figure S5. ${ }^{1} \mathrm{H}$ NMR spectrum of $\mathrm{ZZS}\left(\mathrm{D}_{2} \mathrm{O}, 600 \mathrm{MHz}\right)$.

6. Figure $\mathrm{S} 6 .{ }^{13} \mathrm{C}$ NMR spectrum of ZZS $\left(\mathrm{D}_{2} \mathrm{O}, 600 \mathrm{MHz}\right)$.

7. Figure $\mathrm{S} 7 .{ }^{1} \mathrm{H}$ NMR spectrum of $\mathrm{ZRS}\left(\mathrm{D}_{2} \mathrm{O}, 600 \mathrm{MHz}\right)$.

8. Figure $\mathrm{S} 8 .{ }^{13} \mathrm{C}$ NMR spectrum of $\mathrm{ZRS}\left(\mathrm{D}_{2} \mathrm{O}, 600 \mathrm{MHz}\right)$.

9. Figure $\mathrm{S} 9$. Phase transfer of hydrophobic $\mathrm{Fe}_{3} \mathrm{O}_{4}$ nanoparticles on a large scale.

10. Figure S10. Photographs of oleic acid-capped $\mathrm{Mn}_{3} \mathrm{O}_{4}\left(\mathrm{OLA}-\mathrm{Mn}_{3} \mathrm{O}_{4}\right)$ dispersion and those mixed with ZAS, citric acid (CA), and zwitterionic dopamine sulfonate (ZDS).

11. Figure S11. Supplementary blood serum biochemical indexes of mice at 24 and $72 \mathrm{~h}$ post-injection.

12. Figure S12. Relaxivity measurement of ZAS-NaGdF 4 .

13. Figure S13. Relaxivity measurement of $\mathrm{ZAS}-\mathrm{Fe}_{3} \mathrm{O}_{4}$.

14. Figure S14. $T_{1}$-weighted MR images of three mice before (Pre) and at $10 \mathrm{~min}, 30 \mathrm{~min}$, and $24 \mathrm{~h}$ post-injection of $4.46 \mathrm{~nm} \mathrm{ZAS-NaGdF} 4$ nanoparticles.

15. Figure $\mathrm{S} 15$. Hydrodynamic size of PEG-capped $\mathrm{NaGdF}_{4}$ nanoparticles.

16. Figure S16. Five different perspectives of the 3D MR image of a mouse's vascular system at 23 min after injection of ZAS-NaGdF 4 .

17. Movie $\mathrm{S} 1$. Phase transfer of hydrophobic $\mathrm{Fe}_{3} \mathrm{O}_{4}$ nanoparticles in minutes.

18. Estimation of the Surface Coverage of ZAS on $\mathrm{Fe}_{3} \mathrm{O}_{4}$ Nanoparticles. 


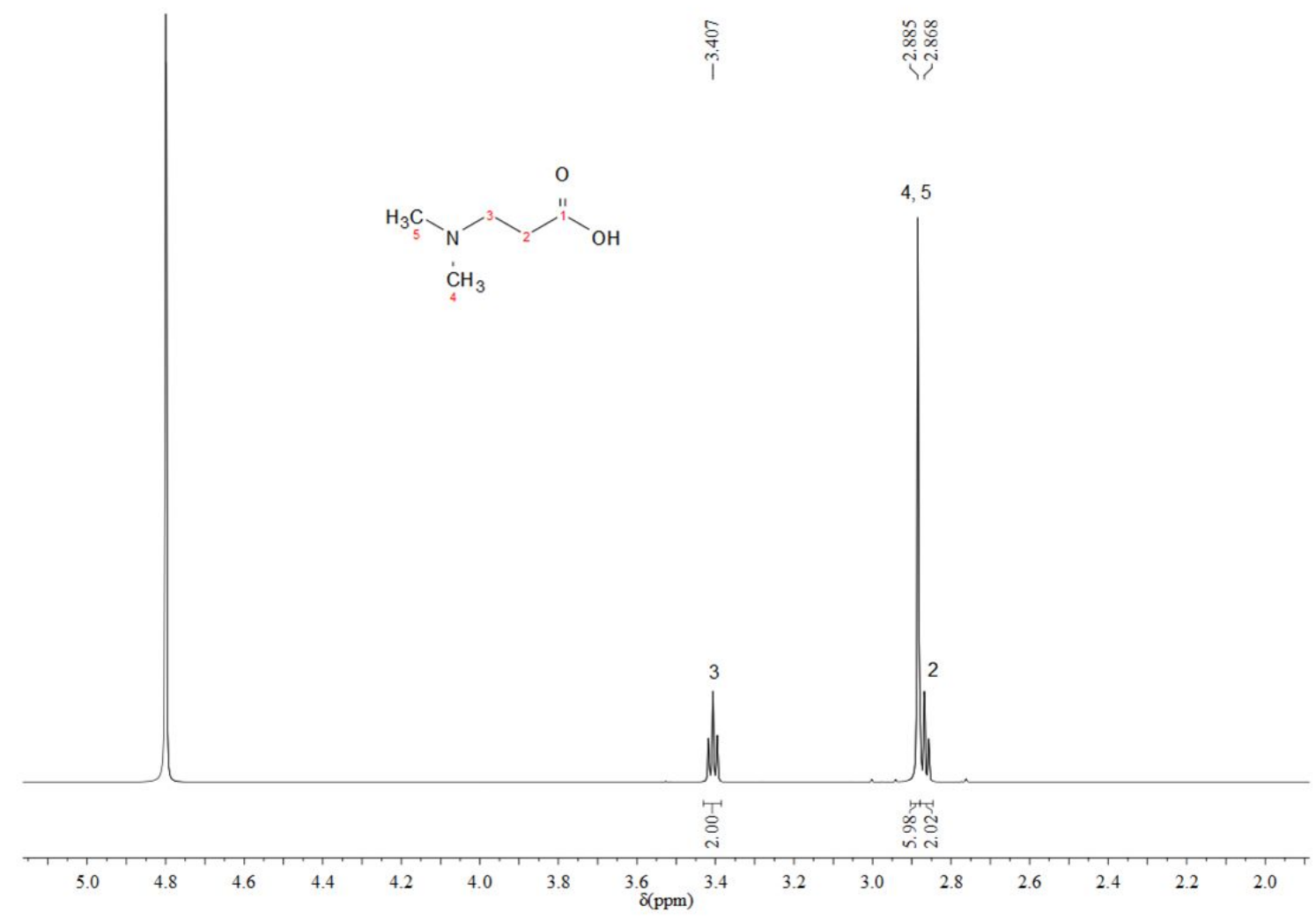

Figure S1. ${ }^{1} \mathrm{H}$ NMR spectrum of 3-dimethylaminopropionic acid $\left(\mathrm{D}_{2} \mathrm{O}, 600 \mathrm{MHz}\right)$.

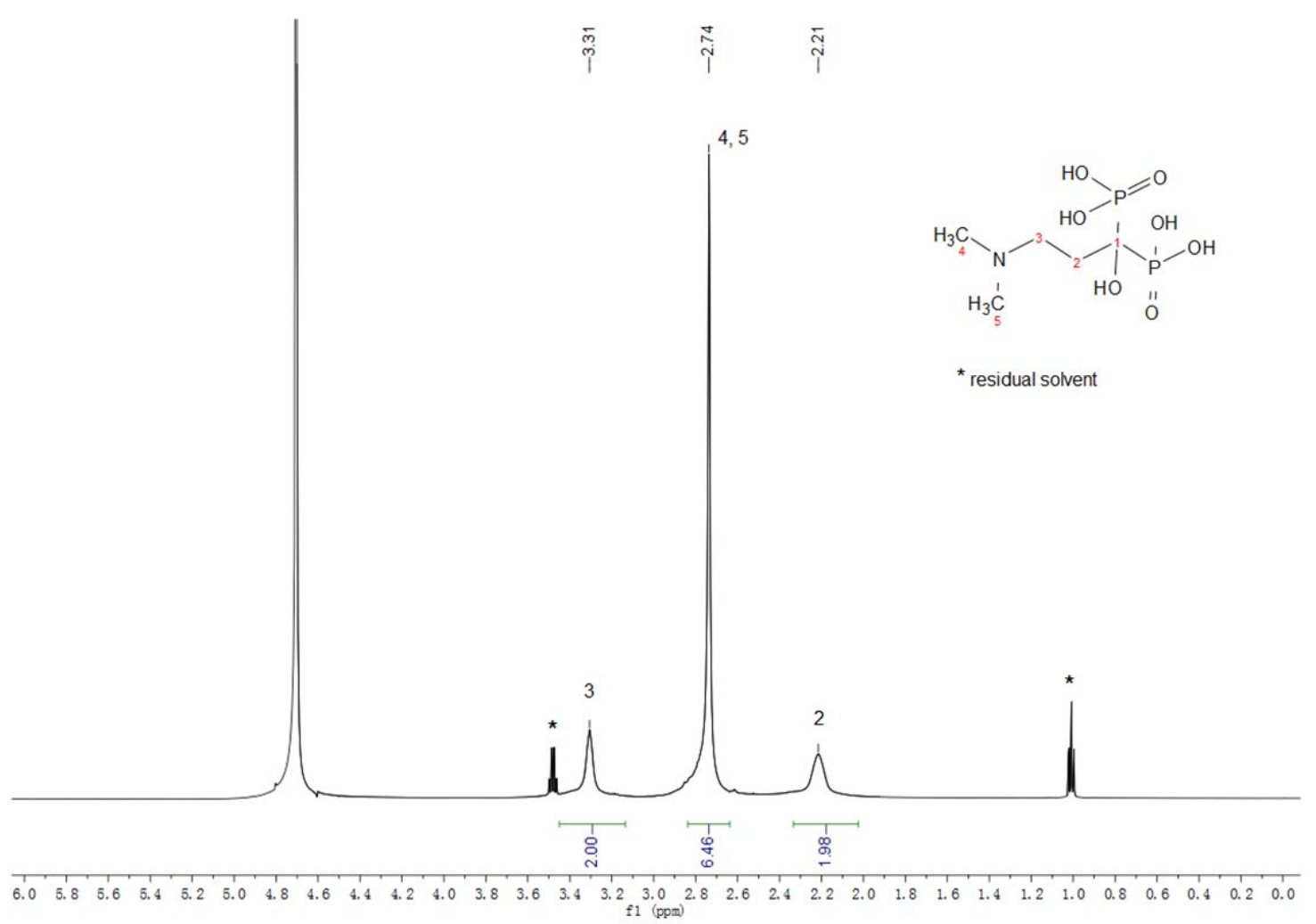

Figure S2. ${ }^{1} \mathrm{H}$ NMR spectrum of [3-(dimethylamino)-1-hydroxypropylidene]diphosphonic acid (olpadronic acid) $\left(\mathrm{D}_{2} \mathrm{O}, 600 \mathrm{MHz}\right)$. 


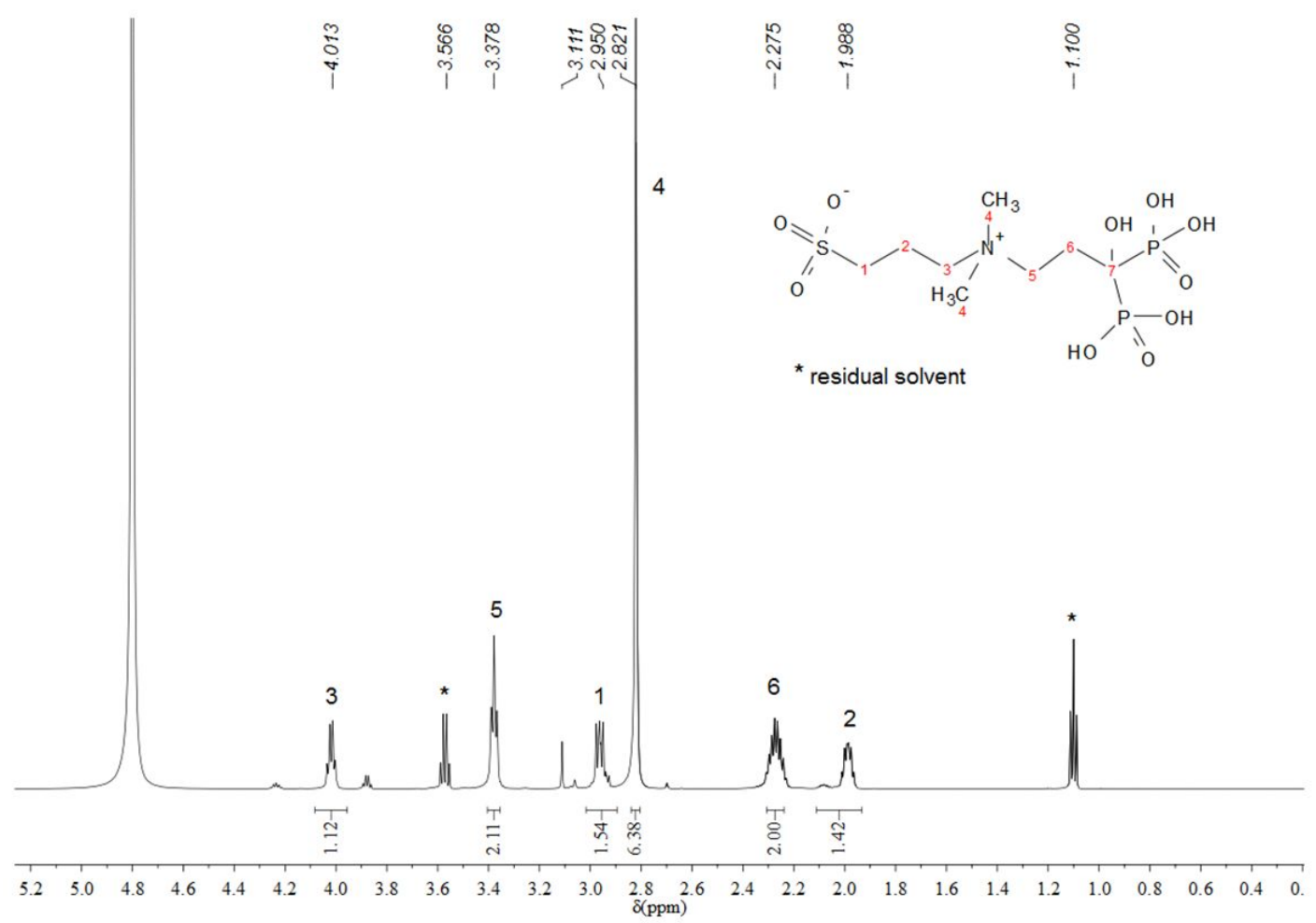

Figure S3. ${ }^{1} \mathrm{H}$ NMR spectrum of ZAS $\left(\mathrm{D}_{2} \mathrm{O}, 600 \mathrm{MHz}\right)$.

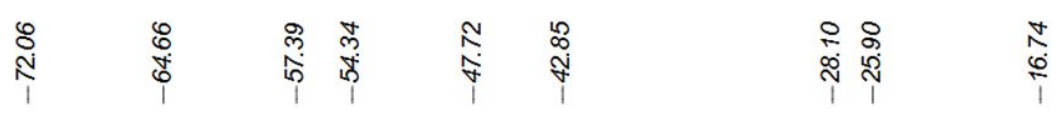

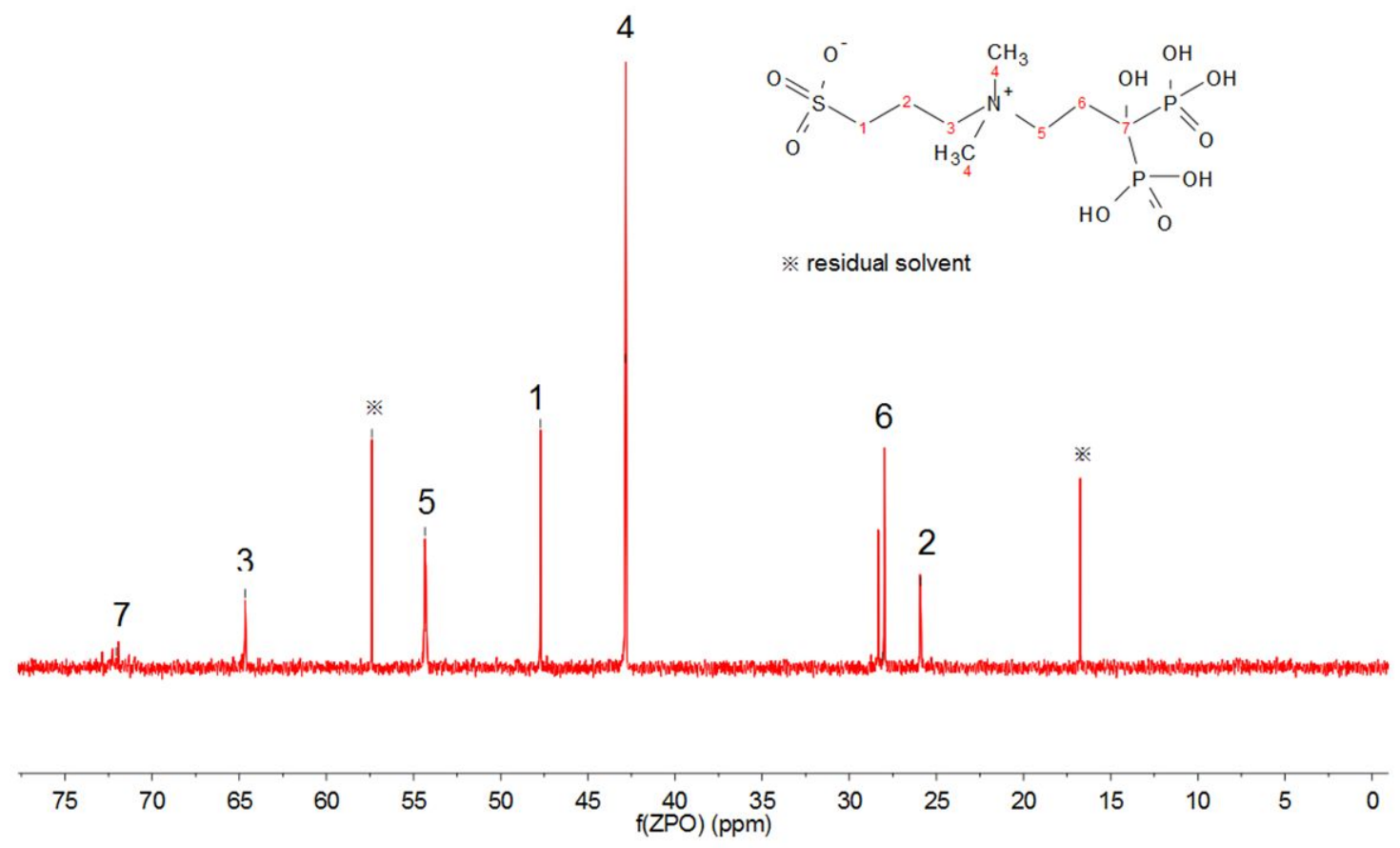

Figure S4. ${ }^{13} \mathrm{C}$ NMR spectrum of $\mathrm{ZAS}\left(\mathrm{D}_{2} \mathrm{O}, 600 \mathrm{MHz}\right)$. 


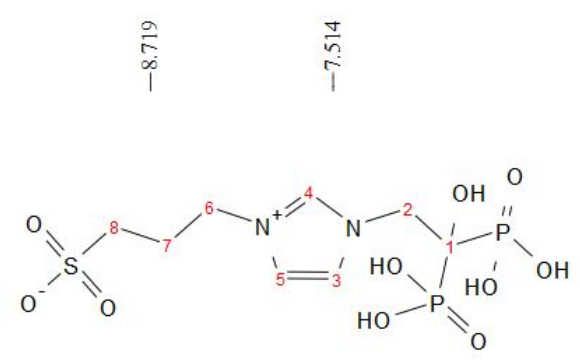

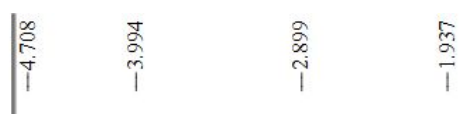

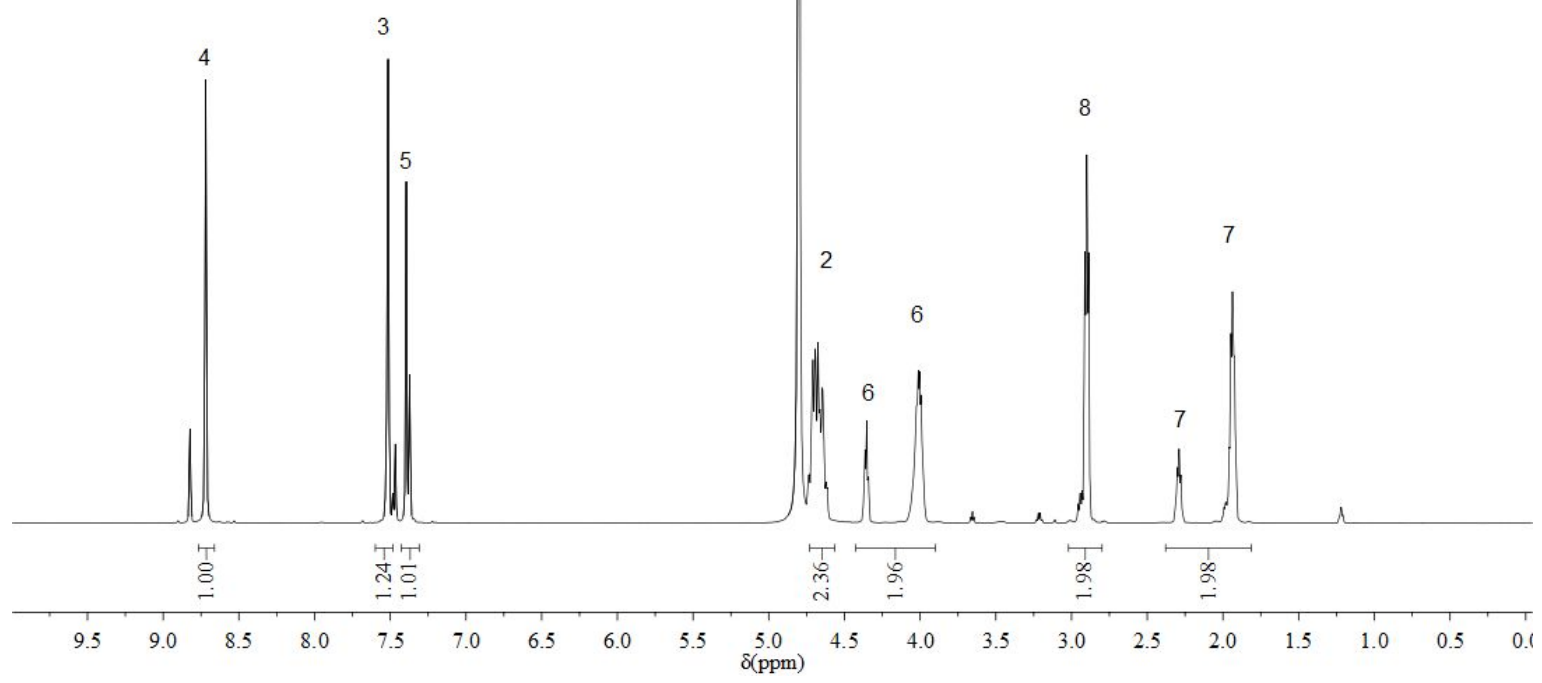

Figure S5. ${ }^{1} \mathrm{H}$ NMR spectrum of $\mathrm{ZZS}\left(\mathrm{D}_{2} \mathrm{O}, 600 \mathrm{MHz}\right)$.
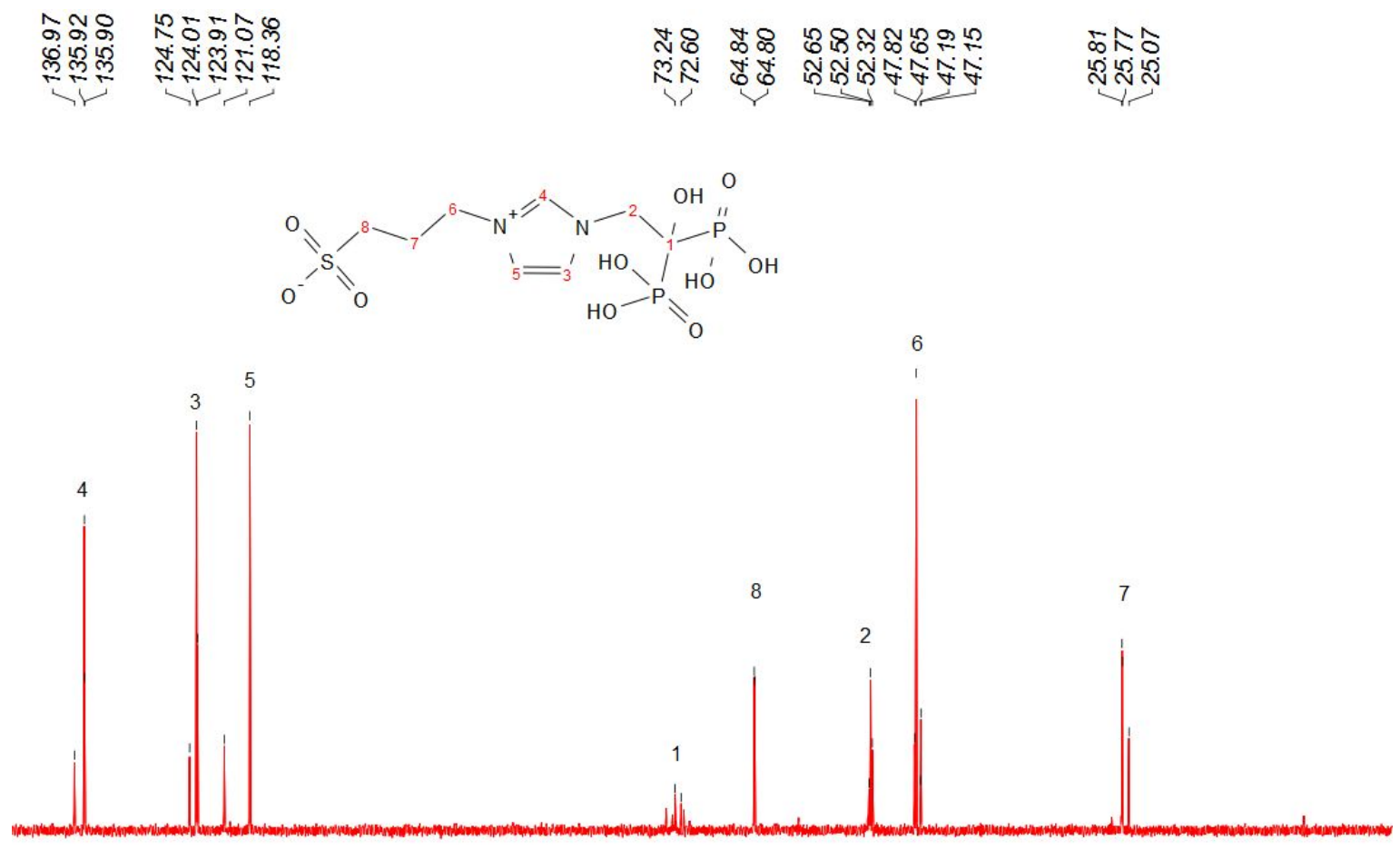

$\begin{array}{llllllllllllllllllllllllllllllll}140 & 135 & 130 & 125 & 120 & 115 & 110 & 105 & 100 & 95 & 90 & 85 & 80 & 75 & 70 & 65 & 60 & 55 & 50 & 45 & 40 & 35 & 30 & 25 & 20 & 15 & 10 & 5 & 0\end{array}$

Figure S6. ${ }^{13} \mathrm{C}$ NMR spectrum of ZZS $\left(\mathrm{D}_{2} \mathrm{O}, 600 \mathrm{MHz}\right)$. 


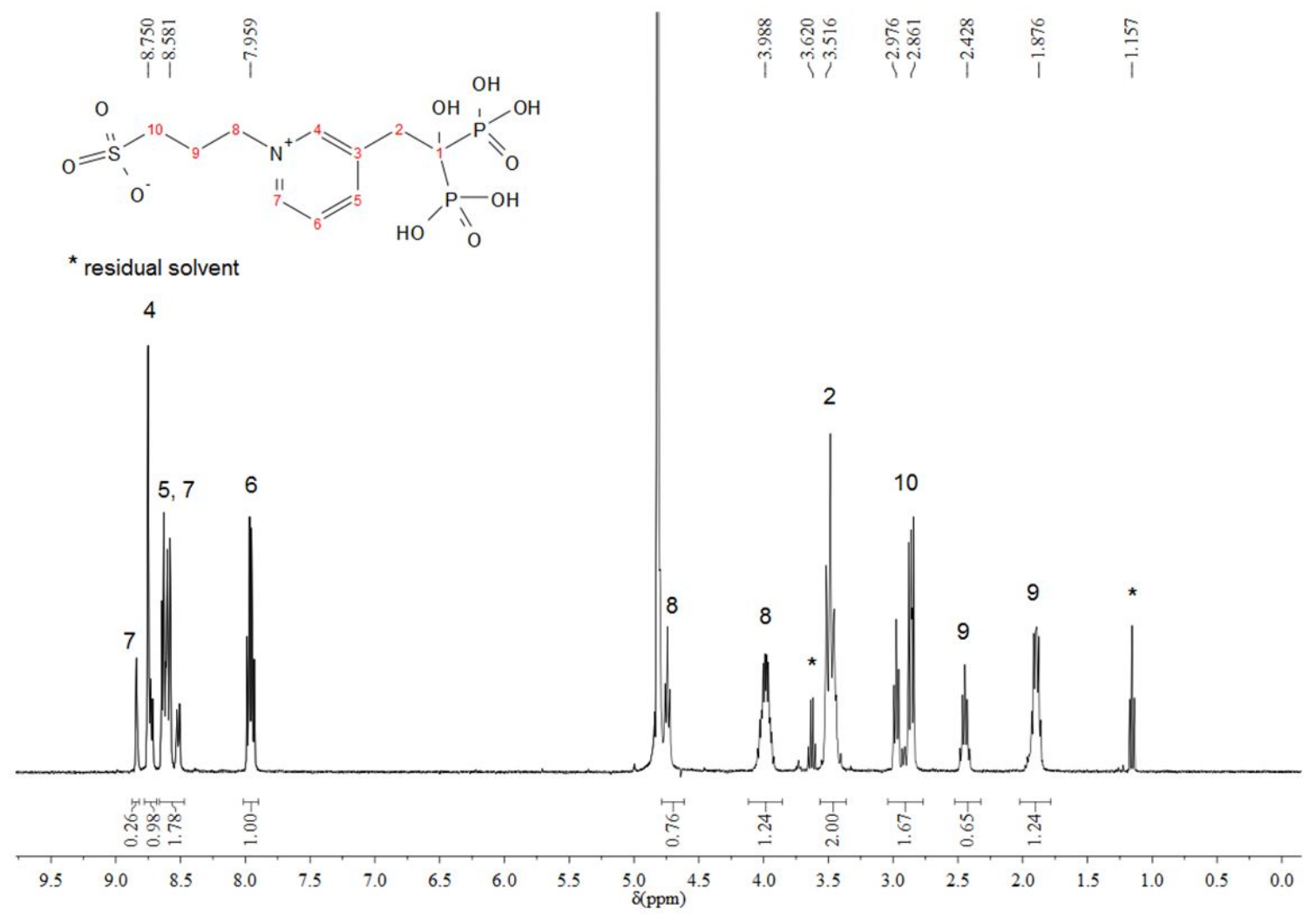

Figure S7. ${ }^{1} \mathrm{H}$ NMR spectrum of $\mathrm{ZRS}\left(\mathrm{D}_{2} \mathrm{O}, 600 \mathrm{MHz}\right)$.

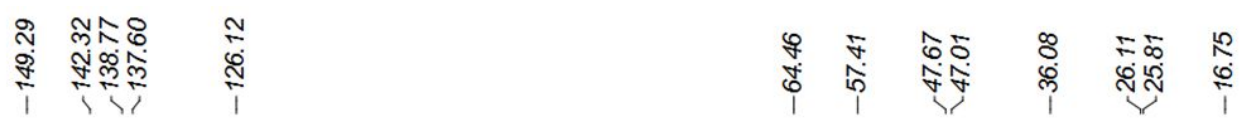<smiles></smiles>

※ residual solvent

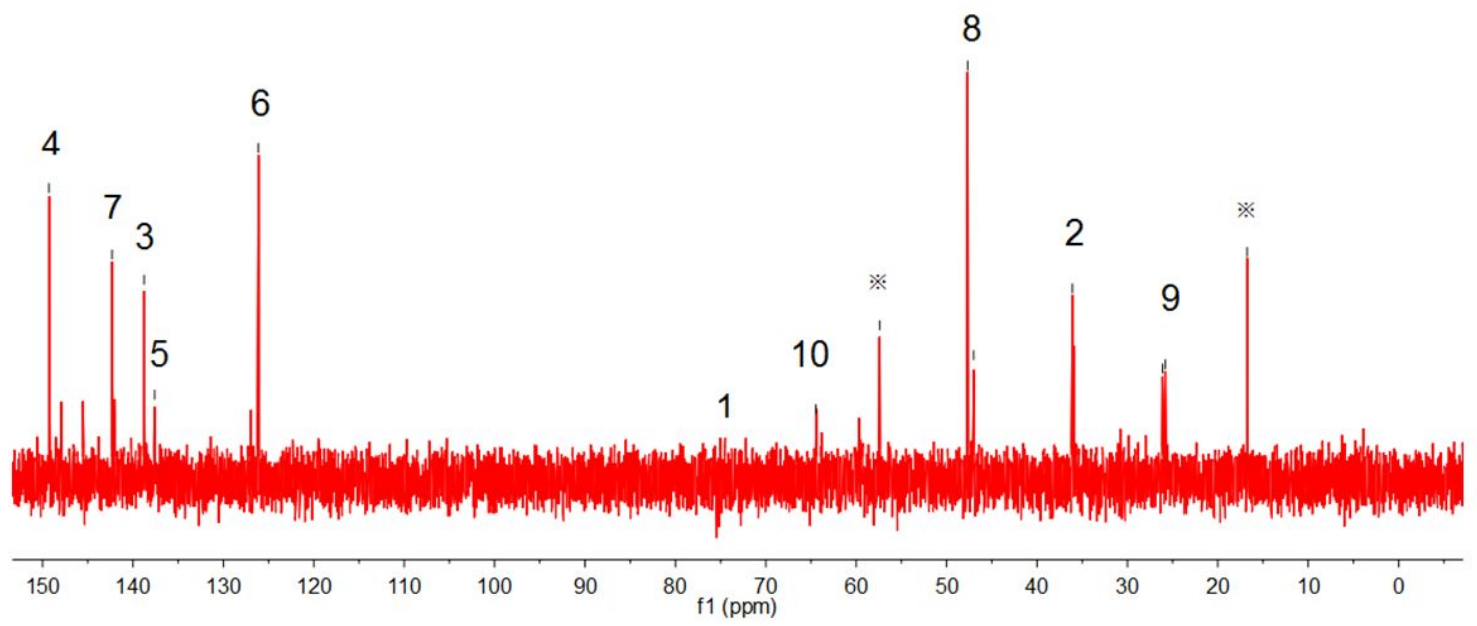

Figure S8. ${ }^{13} \mathrm{C}$ NMR spectrum of ZRS $\left(\mathrm{D}_{2} \mathrm{O}, 600 \mathrm{MHz}\right)$. 

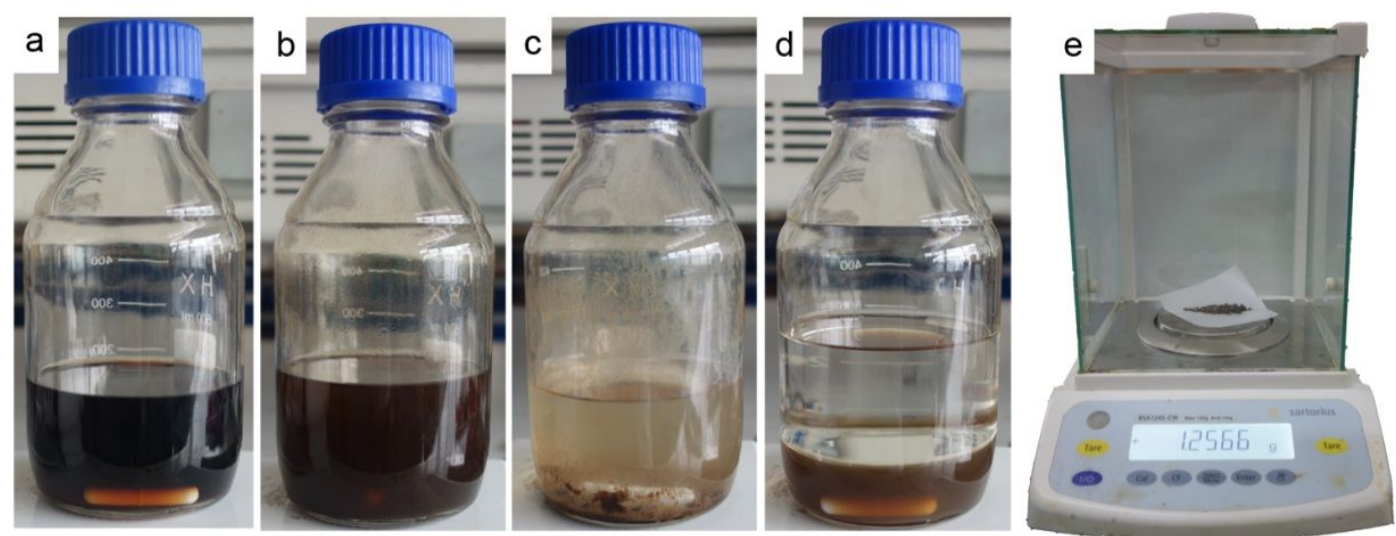

Figure S9. Phase transfer of hydrophobic $\mathrm{Fe}_{3} \mathrm{O}_{4}$ nanoparticles on a large scale. (a) Oleic acid-capped $\mathrm{Fe}_{3} \mathrm{O}_{4}$ nanoparticles dispersed in THF. (b) The solution became turbid after the addition of ZAS. (c) Obvious precipitation appeared after $5 \mathrm{~min}$. The supernatant fraction was replaced by hexane. (d) Water was added to disperse the nanoparticles, forming the aqueous phase at the bottom. (e) Weight of the obtained $\mathrm{ZAS}-\mathrm{Fe}_{3} \mathrm{O}_{4}$ nanoparticles.

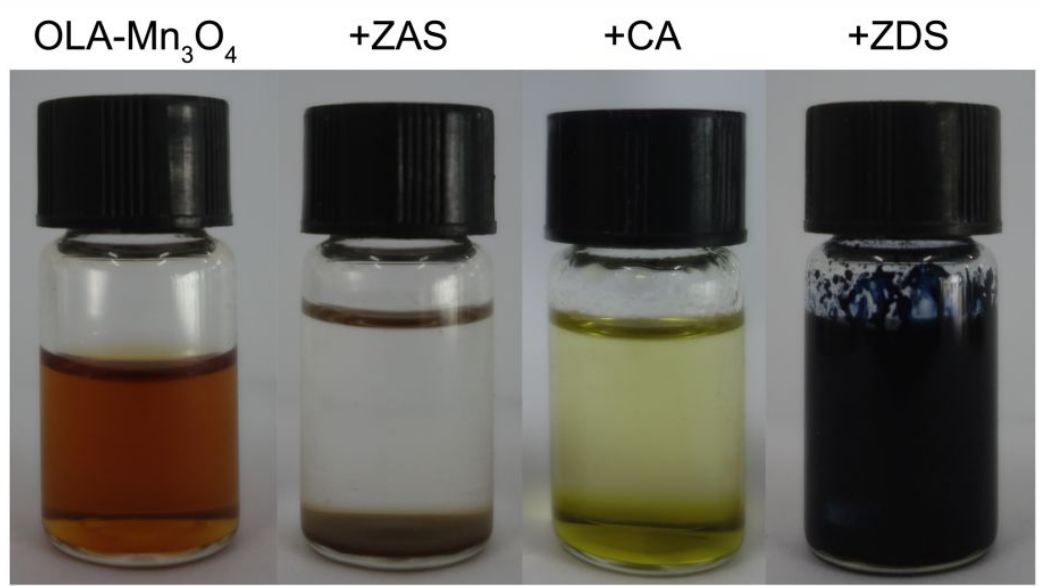

Figure S10. Photographs of oleic acid-capped $\mathrm{Mn}_{3} \mathrm{O}_{4}\left(\mathrm{OLA}-\mathrm{Mn}_{3} \mathrm{O}_{4}\right)$ dispersion and those mixed with ZAS, citric acid (CA), and zwitterionic dopamine sulfonate (ZDS). The yellow color of the solution with CA addition indicates formation of $\mathrm{Mn}^{2+/ 3+}$-citrate complexes. The dark blue color of the solution with ZDS addition can be attributed to the intense ligand-to metal charge transfer between the catechol group of ZAS and $\mathrm{Mn}^{2+}$, which also indicates decomposition $\mathrm{Mn}_{3} \mathrm{O}_{4}$ nanoparticles and formation of $\mathrm{Mn}^{2+}$ complexes. 

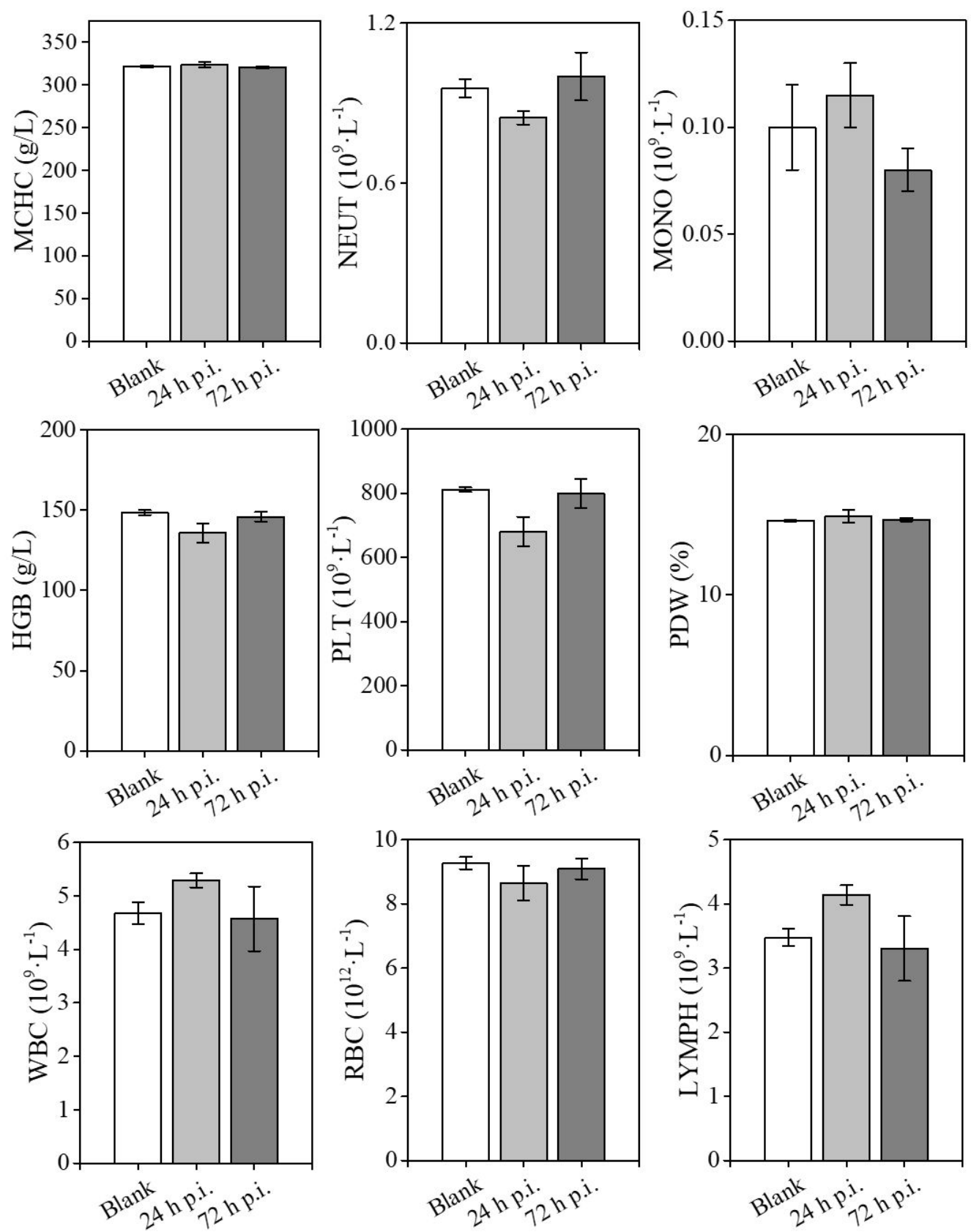

Figure S11. Supplementary blood serum biochemical indexes of mice at 24 and $72 \mathrm{~h}$ post-injection. 
A

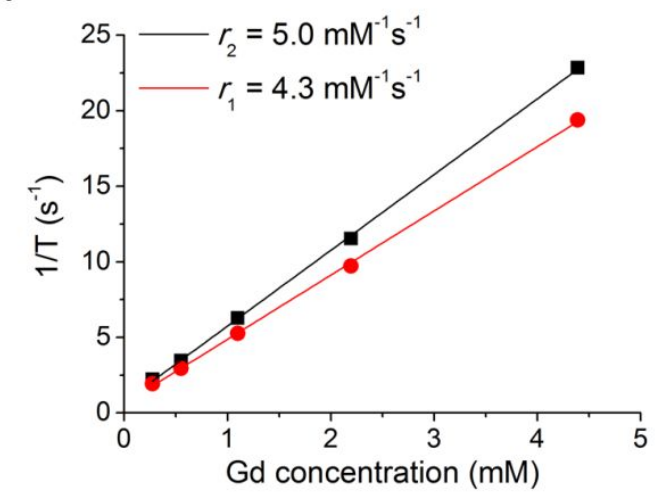

B

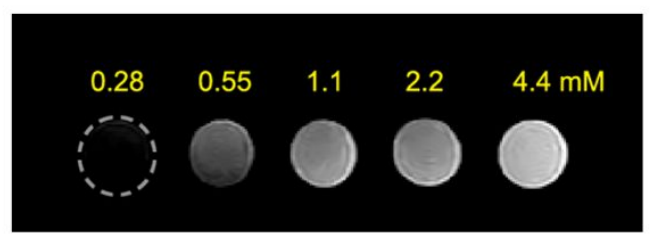

Figure S12. Relaxivity measurement of ZAS-NaGdF 4 . (A) $T_{1}$ and $T_{2}$ relaxation rates $\left(1 / T_{1}, 1 / T_{2}\right)$ plotted against the Gd concentration for determination of the longitudinal $\left(r_{1}\right)$ and transverse $\left(r_{2}\right)$ relaxivities of ZAS-NaGdF 4 , respectively. (B) $T_{1}$-weighted MR images of $Z$ ZAS-NaGdF 4 aqueous dispersions at different concentrations. The imaging parameters are as follow: Field strength $=1 \mathrm{~T}$, $\mathrm{TR} / \mathrm{TE}=330 \mathrm{~ms} / 18.2 \mathrm{~ms}, \mathrm{NS}=4$, field of view $(\mathrm{FOV})=100 \times 100 \mathrm{~mm}^{2}$, slice thickness $=1.5 \mathrm{~mm}$, matrix $=256 \times 384$.

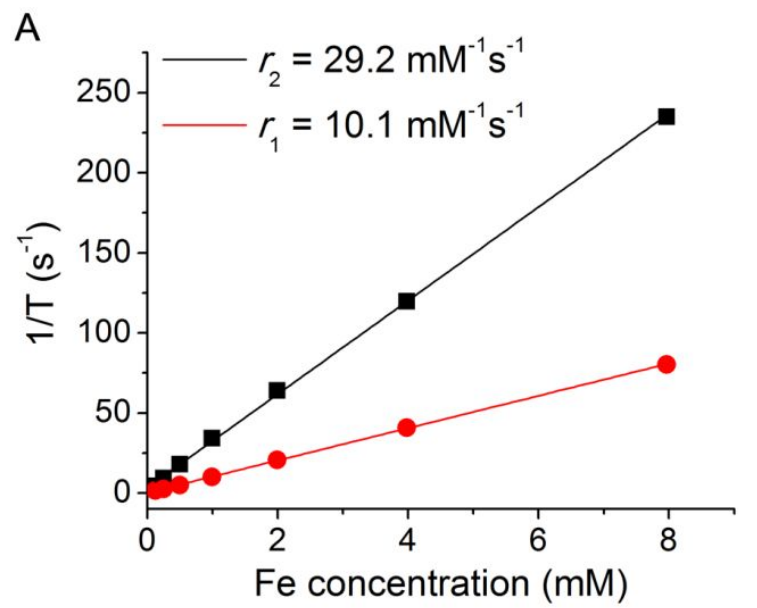

B

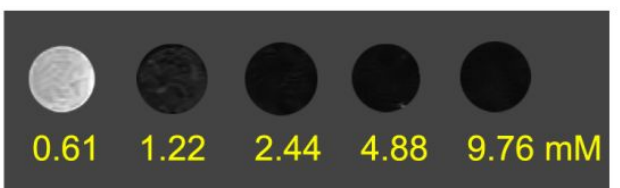

Figure S13. Relaxivity measurement of $\mathrm{ZAS}-\mathrm{Fe}_{3} \mathrm{O}_{4}$. (A) $T_{1}$ and $T_{2}$ relaxation rates $\left(1 / T_{1}, 1 / T_{2}\right)$ plotted against the Fe concentration for determination of the longitudinal $\left(r_{1}\right)$ and transverse $\left(r_{2}\right)$ relaxivities of $\mathrm{ZAS}-\mathrm{Fe}_{3} \mathrm{O}_{4}$, respectively. (B) $T_{2}$-weighted $\mathrm{MR}$ images of $\mathrm{ZAS}-\mathrm{Fe}_{3} \mathrm{O}_{4}$ aqueous dispersions at different concentrations. The imaging parameters are as follow: Field strength $=1 \mathrm{~T}$, $\mathrm{TR} / \mathrm{TE}=1500 \mathrm{~ms} / 80 \mathrm{~ms}, \mathrm{NS}=4$, field of view $(\mathrm{FOV})=100 \times 100 \mathrm{~mm}^{2}$, slice thickness $=1.5 \mathrm{~mm}$, matrix $=256 \times 384$. 


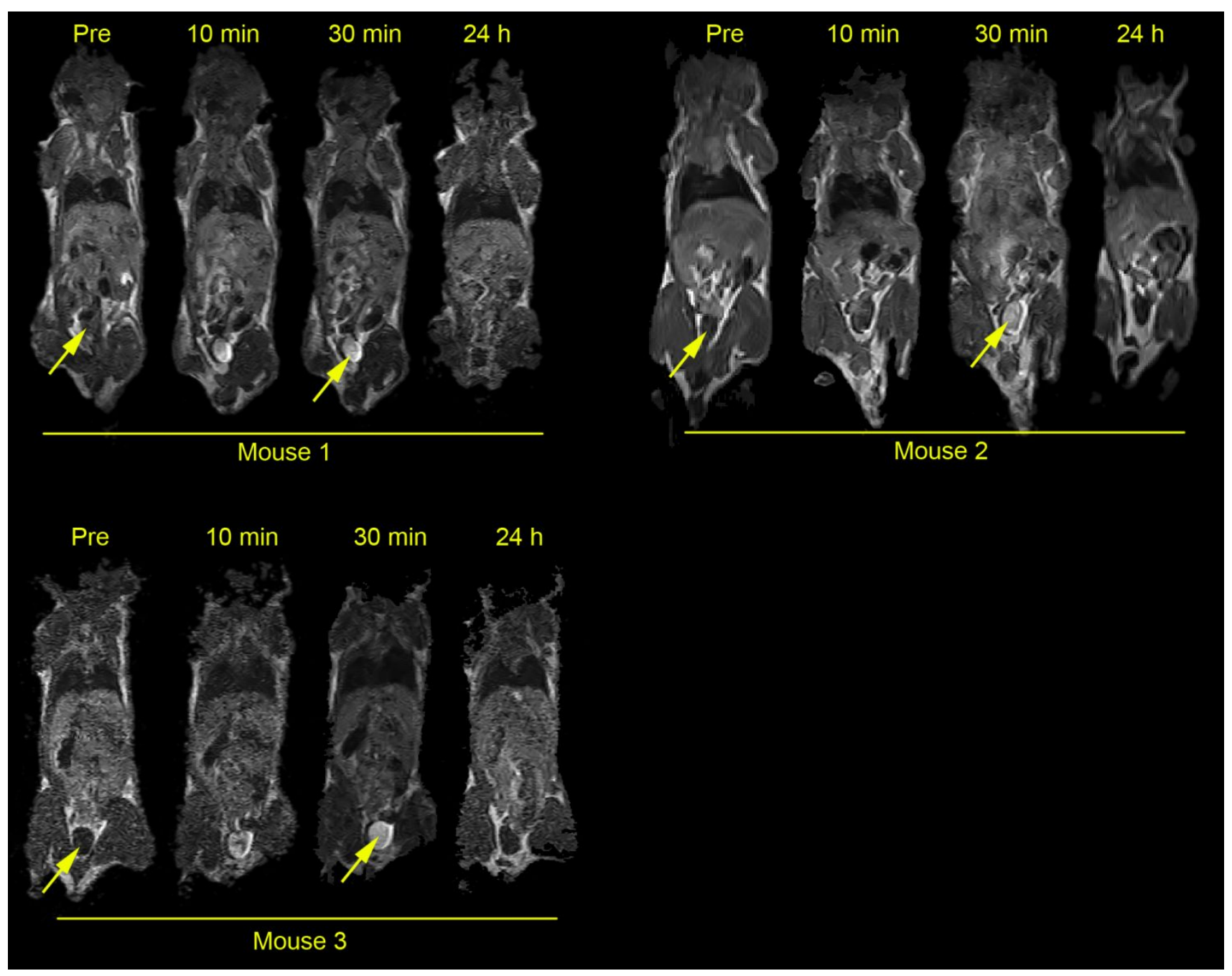

Figure S14. $T_{1}$-weighted MR images of three mice before (Pre) and at $10 \mathrm{~min}, 30 \mathrm{~min}$, and $24 \mathrm{~h}$

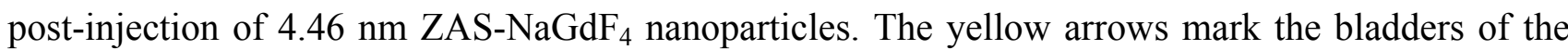
mice.

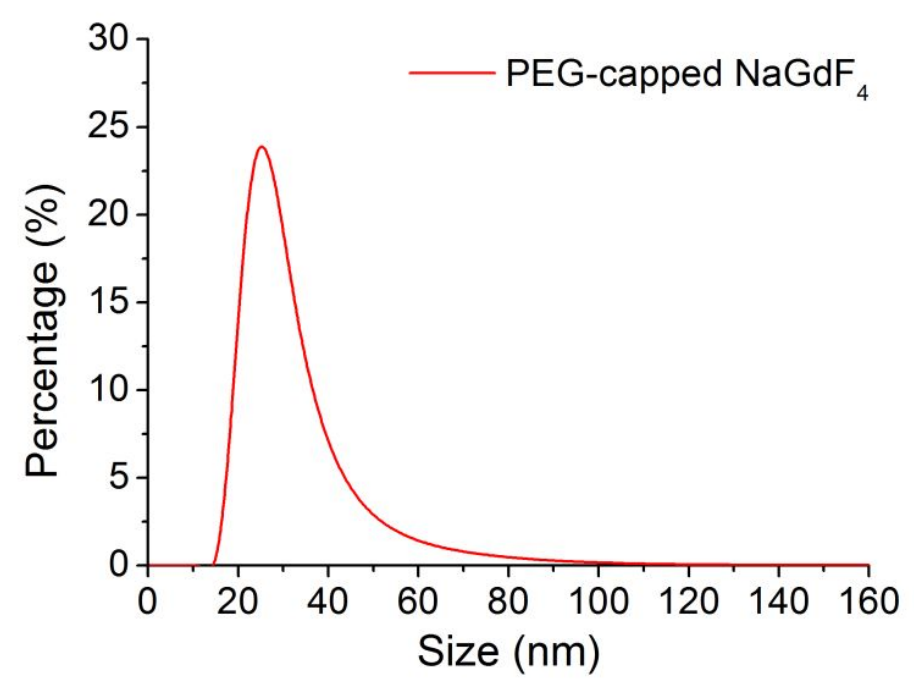

Figure S15. Hydrodynamic size of PEG-capped $\mathrm{NaGdF}_{4}$ nanoparticles. 


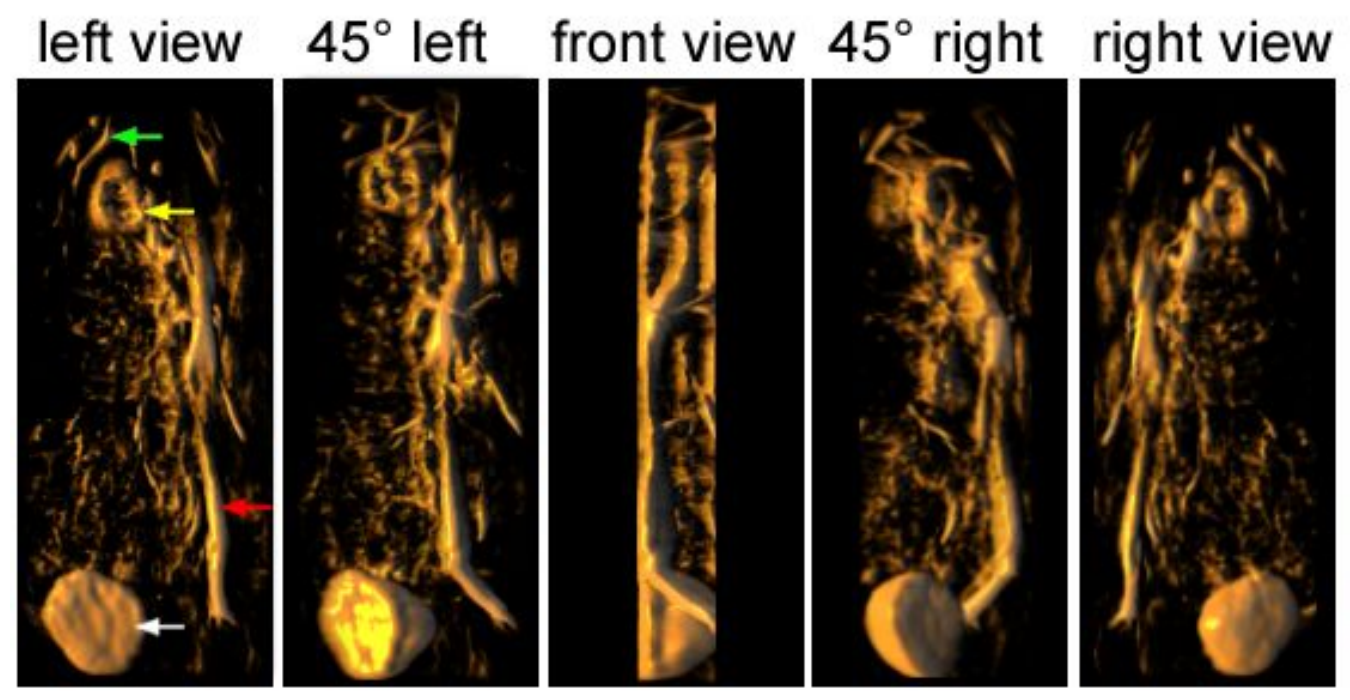

Figure S16. Five different perspectives of the 3D MR image of a mouse's vascular system at $23 \mathrm{~min}$ after injection of $\mathrm{ZAS}-\mathrm{NaGdF}_{4}$. The red, yellow, green, and white arrows mark the vena cava, kidney, vessels in the liver, and bladder, respectively.

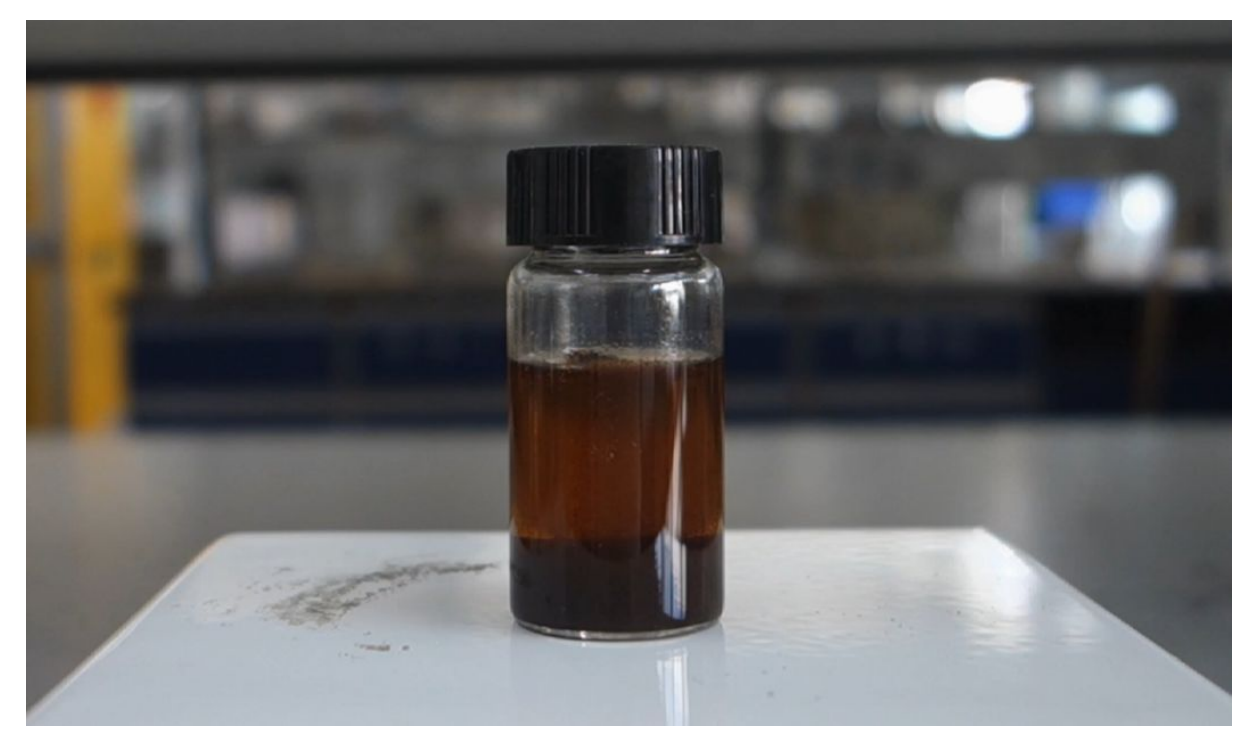

Movie S1. Phase transfer of hydrophobic $\mathrm{Fe}_{3} \mathrm{O}_{4}$ nanoparticles in minutes. Oleic acid-capped hydrophobic $\mathrm{Fe}_{3} \mathrm{O}_{4}$ nanoparticles were dispersed in $5 \mathrm{~mL}$ of THF to make a homogenous dispersion. Then, $1 \mathrm{~mL}$ of ZAS $(25 \mathrm{mg} / \mathrm{mL})$ was added. The mixture was stirred vigorously for $5 \mathrm{~min}$, and the solution gradually turned opaque. After stirring ceased, the particles gradually precipitated to the bottom of the vial, indicating displacement of the original oleic acids on the surface of the particles by ZAS. 


\section{Estimation of the Surface Coverage of $\mathrm{ZAS}$ on $\mathrm{Fe}_{3} \mathrm{O}_{4}$ Nanoparticles.}

The iron oxide nanoparticles are modeled as effective spheres with an average diameter of $\mathrm{D}=9.1$ $\mathrm{nm}$ and a density of $\rho=5.2 \mathrm{~g} / \mathrm{cm}^{3}$, and then the mass $\left(\mathrm{m}_{\mathrm{p}}\right)$ and surface area $\left(\mathrm{S}_{\mathrm{p}}\right)$ of a single particle can be estimated.

$$
\begin{gathered}
m_{p}=\rho \cdot \frac{4}{3} \pi\left(\frac{D}{2}\right)^{3}=2.05 \times 10^{-18} \mathrm{~g} \\
S_{p}=4 \pi\left(\frac{D}{2}\right)^{2}=260 \mathrm{~nm}^{2}
\end{gathered}
$$

Based on the TGA curve shown in Figure 2C, the organic (ZAS) and inorganic $\left(\mathrm{Fe}_{3} \mathrm{O}_{4}\right)$ materials constitute about $36.4 \%$ and $57.0 \%$ by weight of the total mass, respectively. Then, the mass $\left(\mathrm{m}_{\mathrm{o}}\right)$ of ZBP ligands coating on a single nanoparticle can be estimated.

$$
m_{o}=\frac{36.4 \%}{57.0 \%} \times 2.05 \times 10^{-18} \mathrm{~g}=1.31 \times 10^{-18} \mathrm{~g}
$$

Thus, the surface coverage (C) of ZAS on $\mathrm{Fe}_{3} \mathrm{O}_{4}$ nanoparticles can be determined.

$$
\mathrm{C}=\frac{m_{o} \cdot N_{A} / M}{S_{p}}
$$

Where, $\mathrm{M}$ is the molecular weight of ZAS $(385.27 \mathrm{~g} / \mathrm{mol}) . \mathrm{N}_{\mathrm{A}}$ is the Avogadro constant. Thus, $\mathrm{C}$ was calculated to be 8 molecules $/ \mathrm{nm}^{2}$. 